\title{
Substrate Conditions and Abundance of Lake Trout Eggs in a Traditional Spawning Area in Southeastern Lake Michigan ${ }^{1}$
}

\author{
John A. Dorr III, Daniel V. O'Connor, ${ }^{2}$ Neal R. Foster, ${ }^{2}$ \\ AND DAVID J. JUdE \\ Great Lakes Research Division, University of Michigan \\ Ann Arbor, Michigan 48109
}

\begin{abstract}
Spawning by planted lake trout (Salvelinus namaycush) was documented by sampling with a diver-assisted pump in a traditional spawning area in southeastern Lake Michigan near Saugatuck, Michigan in mid-November in 1978 and 1979. Bottom depths at the 11 locations sampled ranged from 3 to $12 \mathrm{~m}$ and substrate size from boulders to sand. Periphyton (Cladophora and associated biota) was several millimeters thick at most stations but sparse at the shallowest. The most eggs recovered from a single sample occurred at the shallowest depth $(3 \mathrm{~m})$. In both years, some of the small numbers of eggs collected ( 9 in 1978, 14 in 1979) were alive and fertilized. Laboratory incubation of viable eggs resulted in successful hatching of larvae. When compared with egg densities measured at spawning sites used by self-sustaining populations of lake trout in other lakes, densities in the study area $\left(0-13 / \mathrm{m}^{2}\right)$ appeared to be critically low. Insufficient numbers of eggs, combined with harsh incubation conditions (turbulence, ice scour, sedimentation), were implicated as prime causes for lake trout reproductive failure in the study area, although other factors, such as inappropriate spawning behavior (selection of suboptimal spawning location, depth, or substrate) also may have reduced survival of eggs and larvae.
\end{abstract}

Before the decline of lake trout (Salvelinus namaycush) in Lake Michigan during the late 1940 's and their apparent extinction in the early 1950's (Eschmeyer 1957), commercial production of the species remained relatively stable for several decades (Wells and McLain 1973). The decline and eventual extinction have been attributed to several factors, including sea lamprey (Petromyzon marinus) predation (Wells and McLain 1973) and overfishing (Smith 1968; Christie 1974). Martin and Olver (1976) cited eutrophication in Ontario lakes, particularly in marginal lakes or waters along the southern limit of the natural range of lake trout, as contributing to loss of trout populations. In 1965, after sea lamprey control had been initiated, rehabilitation of Lake Michigan lake trout pop-

\footnotetext{
${ }^{1}$ Contribution 311 of the Great Lakes Research Division, University of Michigan, Ann Arbor, Michigan, and Contribution 581 of the Great Lakes Fishery Laboratory, 1451 Green Road, Ann Arbor, Michigan 48105 .

${ }^{2}$ Great Lakes Fishery Laboratory, United States Fish and Wildlife Service, 1451 Green Road, Ann Arbor, Michigan 48105.
}

ulations (coordinated by the Great Lakes Fishery Commission) began; from 1965 to 1979 , nearly 34 million lake trout were planted in Lake Michigan (Brown et al., in press).

Despite recent success of the stocking program and growth of a substantial sport fishery, lake trout in Lake Michigan have shown little evidence of natural recruitment beyond early fry stages. This apparent reproductive failure has been attributed to a variety of causes: (1) eutrophication and associated sedimentation and suffocation of eggs (Martin 1957; Martin and Olver 1976, 1980), (2) toxic substances (Stauffer 1979; Willford 1980), (3) predation (Scott and Crossman 1973; Stauffer and Wagner 1979; Martin and Olver 1980), (4) insufficient numbers of spawners or inappropriate stocking methods (Pycha 1972; Swanson 1973; Peck 1979; Rybicki and Keller 1978; Brown et al., in press), and (5) genetically influenced stock- or strain-specific differences associated with egg development, behavior, or reproduction that might adversely affect survival in the wild (Loftus 1976; Brown et al., in press). It is also possible that several of these processes act together to reduce reproductive success.

Knowledge of the extent to which lake trout 


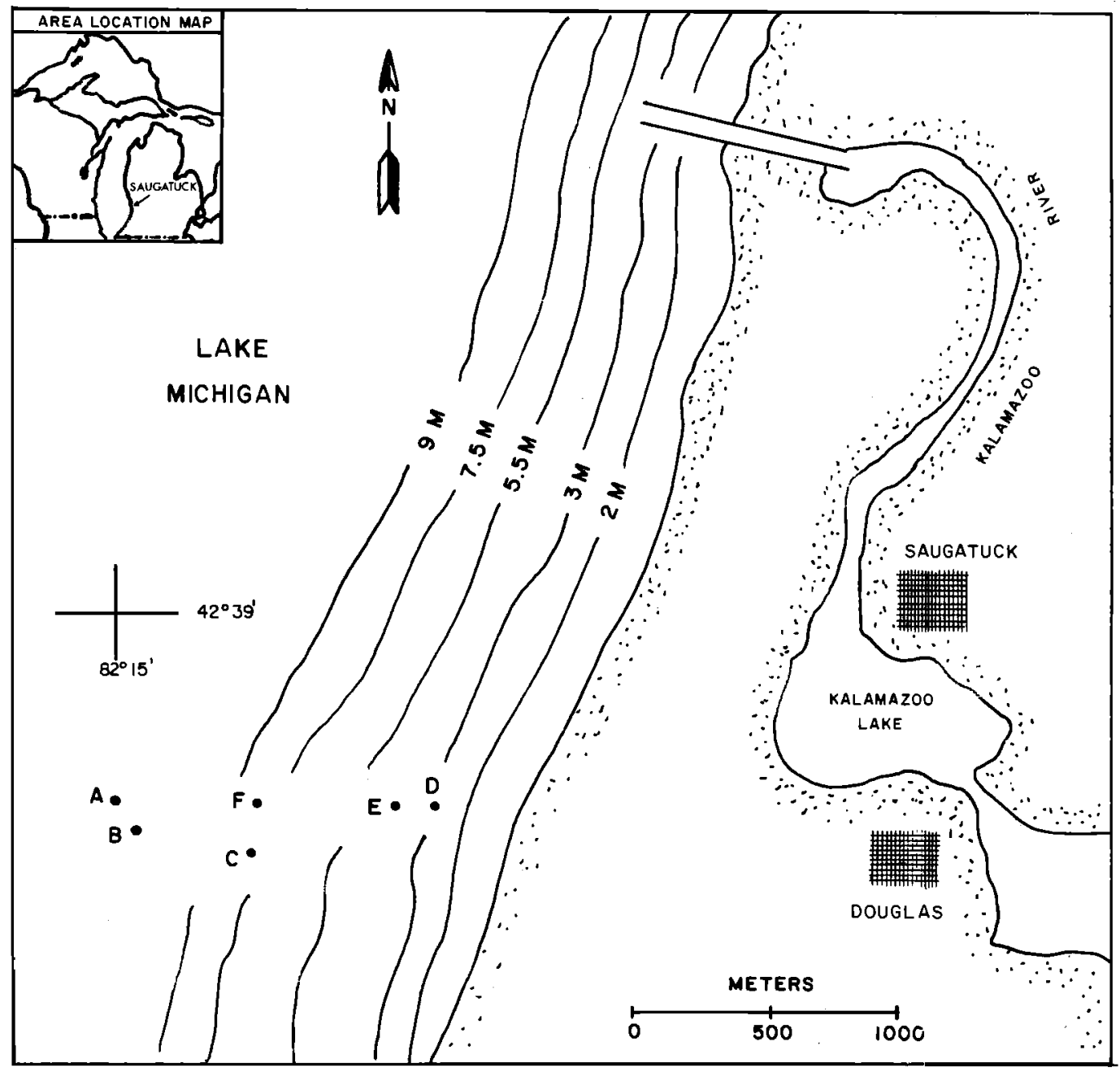

FIGURE 1.-Location of sampling stations established to evaluate lake trout reproduction in southeastern Lake Michigan near Saugatuck, Michigan, 1978 (stations $A-C$ ) and 1979 (stations $D-F$ ).

of hatchery origin can reproduce successfully on natural substrates (traditional spawning reefs), as well as on artificial substrates, is needed to assess the potential for reestablishing selfsustaining trout populations in the lake. Also needed is information on the spawning and incubation requirements of introduced stocks of lake trout and the extent to which their reproductive success may be limited by substrate conditions.

We examined a reef in a traditional spawning area in southern Lake Michigan to determine if lake trout spawning had occurred and to assess some environmental conditions that might affect incubation. Egg densities were estimated from sampling data, and the live eggs collected were incubated in the laboratory to assess viability and developmental potential.

\section{Methods}

The study site was in southeastern Lake Michigan about $2.5 \mathrm{~km}$ south of the harbor entrance at Saugatuck, Michigan (Fig. 1). The sampling area was located near Douglas, Michigan in an isolated exposure of glacial moraine that extends several kilometers southward from Douglas, and from shore to depths as great as $20 \mathrm{~m}$. Substrate materials in this general region 
of the lake consist predominantly of shifting sand; the bottom profile is typically flat and unbroken. However, substrates in the sampling area included boulders $(0.5-2.0 \mathrm{~m}$ in diameter), cobbles, and gravels, as well as occasional sand ( $4.5 \mathrm{~m}$ or less). Rock surfaces were smooth and rounded.

On 16 November 1978, we sampled at three stations (Fig. 1): Station A was at the 12-m depth contour and directly offshore from a boulder ( $4 \mathrm{~m}$ in diameter and exposed at the shoreline) which served as a permanent location marker; Station B was at a depth of $11 \mathrm{~m}$ and about $100 \mathrm{~m}$ southeast of Station $\mathrm{A}$; and Station $C$ was at $8 \mathrm{~m}$ about $200 \mathrm{~m}$ southeast of Station A. The next year, 14 November 1979, three different stations were sampled on a straight-line transect extending perpendicular to shore from the boulder. Station D was at 3 $\mathrm{m}, \mathrm{E}$ at $4.5 \mathrm{~m}$, and $\mathrm{F}$ at $8 \mathrm{~m}$. Further sampling details are given in Table 1 . Different depths were sampled during the 2-year study in an attempt to bracket any depth-selective spawning. Severe weather, as well as scheduling constraints, precluded further sampling.

Each sample came from two adjacent $0.5-\mathrm{m}^{2}$ areas (quadrats) of bottom, pooled to represent $1 \mathrm{~m}^{2}$ of bottom. The $0.5-\mathrm{m}^{2}$ areas were delineated by a square sheet-metal frame $4 \mathrm{~cm}$ deep and $71 \mathrm{~cm}$ on a side, then vacuumed by a diver using a hand-held hose, $3.8-\mathrm{cm}$ diameter, connected to a surface-operated, gasoline-powered centrifugal pump (designed after Manz 1964). As a quadrat was vacuumed, the diver turned over small rocks and stirred the water gently to try to dislodge eggs wedged in the substrate. Eggs mixed with bottom debris were collected in a wire-mesh basket suspended in a vacuumtight, 115-liter drum located ahead of the pump to reduce shear, turbulence, and abrasion to the eggs. Upon removal of eggs from the collection basket, translucent (potentially viable) eggs were separated from opaque (unfertilized, moribund, or dead) eggs and put into 1 -liter, glass jars that were capped and stored in a 55-liter ice chest filled with lake water. Water temperature in the jars was maintained within $1.5 \mathrm{C}$ of ambient lake temperature during transport to the laboratory. Opaque eggs were segregated by sample and preserved in a $5 \%$ formaldehyde solution. Within 12 hours after collection, potentially viable eggs were transferred to a laboratory incubation system
TABLE 1.-Summary of data on lake trout eggs collected in southeastern Lake Michigan near Saugatuck, Michigan, 16 November 1978 and 14 November 1979. Each sample was composed of two $0.5-\mathrm{m}^{2}$ bottom areas vacuumed with a diver-directed suction pump hose.

\begin{tabular}{|c|c|c|c|}
\hline \multirow{2}{*}{$\begin{array}{c}\text { Year, station, } \\
\text { depth, water } \\
\text { temperature } \\
\text { and sample } \\
\text { number }\end{array}$} & \multirow{2}{*}{$\begin{array}{c}\text { Substrate } \\
\text { composition }^{a}\end{array}$} & \multicolumn{2}{|c|}{$\begin{array}{l}\text { Number of } \\
\text { eggs collected }\end{array}$} \\
\hline & & Total & Live \\
\hline \multicolumn{4}{|l|}{1978} \\
\hline \multicolumn{4}{|c|}{$A(12.0 \mathrm{~m}, 10 \mathrm{C})$} \\
\hline 1 & C, G, St (0.5) & 2 & 1 \\
\hline 2 & B, C, G, St (I) & & \\
\hline 3 & $\mathrm{~B}, \mathrm{C}, \mathrm{G}, \mathrm{St}$ & & \\
\hline \multicolumn{4}{|c|}{$\mathrm{B}(11.0 \mathrm{~m}, 10.0 \mathrm{C})$} \\
\hline 1 & B, C, G, St (1-2) & $3^{\mathrm{b}}$ & \\
\hline 2 & B, C, G, St (1) & & \\
\hline 3 & C, G, St (1) & & \\
\hline \multicolumn{4}{|c|}{$\mathrm{C}(8.0 \mathrm{~m}, 10 \mathrm{C})$} \\
\hline 1 & B, C, G, St (1) & 2 & \\
\hline 2 & C, G, St (1) & 2 & 1 \\
\hline \multicolumn{4}{|l|}{1979} \\
\hline \multicolumn{4}{|c|}{$\mathrm{D}(3.0 \mathrm{~m}, 7.8 \mathrm{C})$} \\
\hline 1 & $\mathrm{~B}, \mathrm{C}, \mathrm{G}, \mathrm{St}$ & 13 & 4 \\
\hline \multicolumn{4}{|c|}{$\mathrm{E}(4.5 \mathrm{~m}, 7.9 \mathrm{C})$} \\
\hline 1 & $\mathrm{C}, \mathrm{Sd}, \mathrm{St}$ & & \\
\hline \multicolumn{4}{|c|}{$\mathrm{F}(8.0 \mathrm{~m}, 8.6 \mathrm{C})$} \\
\hline 1 & B, C, G, Sd, St & 1 & 1 \\
\hline
\end{tabular}

a Abbreviations: $\mathrm{B}=$ boulder, $\mathrm{C}=$ cobble, $\mathrm{G}=$ gravel, $\mathrm{Sd}=$ sand, $\mathrm{St}=$ silt. Thickness of silt $(\mathrm{mm})$ given in parentheses; where no value appears, silt was negligible. Surficial substrates were arbitrarily classified by diameter: boulder $=$ $>30 \mathrm{~cm}$, cobble $=5-30 \mathrm{~cm}$, gravel $=0.1-5.0 \mathrm{~cm}$, and sand $=<0.1 \mathrm{~cm}$. Silt was composed of sediment and organic detritus.

b Includes one egg membrane.

at the Great Lakes Fishery Laboratory, Ann Arbor, Michigan. In the laboratory, we counted all eggs (live and dead) and attempted to determine whether fertilization had occurred and to what stage development had proceeded. Viable eggs were incubated until they hatched or died. Incubation temperatures ranged from 5.9 to $8.3 \mathrm{C}$ during 1978 ; in 1979 , they were reduced from 6.1 to $0.6 \mathrm{C}$ and gradually returned to $5.3 \mathrm{C}$ in an attempt to simulate the lake water-temperature regime.

\section{Results}

\section{Substrate conditions and associated biota}

A gradation in substrate size from predominantly large boulders interspersed with patches of sand inshore (Station D, $3 \mathrm{~m}$ ) to smaller, 
more homogeneous cobbles offshore (Station A, $12 \mathrm{~m}$ ), was noted by divers. Filamentous periphyton (Cladophora and associated biota) was several millimeters thick at most stations, except at Station D $(3 \mathrm{~m})$, where periphyton was sparse. About $1 \mathrm{~mm}$ of flocculent material (composed of sediment, detached periphyton, and diatomaceous and organic detritus) covered the substrate at deeper stations $(8 \mathrm{~m}$ or more); noticeably less flocculent material was observed at shallow stations ( $4.5 \mathrm{~m}$ or less).

Observations and collections by divers indicated a higher number and diversity of invertebrates (amphipods, mysids, chironomids, ephemeropterans, gastropods, sphaeriids, decapods) in the rocky substrate, indicating more productive and heterogeneous benthic habitat conditions than those in the sand substrate surrounding the reef. No invertebrates were present in samples collected at Station E (a sandy area with isolated clumps of cobbles). Horns has shown that crayfish may prey on lake trout eggs deposited among rocks (Horns and Magnuson, in press). Crayfish also were abundant in this sampling area, and exposed eggs may have been subjected to predation.

Divers also reported the presence of several species of fish, including yellow perch (Perca flavescens), alewife (Alosa pseudoharengus), common carp (Cyprinus carpio), and sculpin (Cottus spp.). Scott and Crossman (1973), Peck (1979), and Stauffer and Wagner (1979) concluded that fish predation did not cause significant mortality of lake trout eggs deposited on northern Lake Michigan spawning reefs, although some of these species have been observed to feed on lake trout eggs.

\section{Density, viability and survival of eggs}

Eight lake trout eggs and one egg membrane were collected in 1978 (Table 1). Eggs were collected in one of the three samples taken at both stations A (12 m) and B (11 m), and both samples taken at Station $\mathrm{C}(8 \mathrm{~m})$ contained eggs. One live egg was found among eggs collected at Station A $(12 \mathrm{~m})$ and at Station C $(8 \mathrm{~m})$. Of the remaining eggs collected in 1978, two fertilized eggs were dead when collected; the other four were too badly damaged during pumping to determine their developmental state. The two live eggs collected in 1978 were incubated at the laboratory and, after 49 days, one egg died of unknown causes but was subsequently determined to have been fertile. The other egg hatched between the 58th and 59th day of incubation. The larva survived an additional 1516 days, absorbed some of its yolk-sac, but did not attain the exogenous feeding stage and died of undetermined causes on the 84th day of incubation (at a length of $19 \mathrm{~mm}$ ).

Fourteen eggs were collected during 1979 (Table 1), of which 13 were collected at Station D $(3 \mathrm{~m})$. Divers reported observing 5-10 eggs within a few meters of the sampling quadrats. Of the 13 eggs collected at Station D, 4 were alive, 3 were dead but appeared to have reached the 10-14-day developmental stage, and the other 6 were too damaged to assess their developmental state. No eggs were collected at Station E $(4.5 \mathrm{~m})$, the area of sandy substrate. One live egg was collected at Station $\mathrm{F}(8 \mathrm{~m})$, and the diver counted three additional eggs within $1 \mathrm{~m}$ of the sampling quadrats. The five live eggs were incubated as in 1978; two eggs died on the second day of incubation, one on the third day, and one on the 48th day. The remaining egg hatched on Day 172 . Lower incubation temperatures $(0.6-6.1 \mathrm{C})$ accounted for the longer incubation period observed for the $1979 \mathrm{egg}$, compared with the $1978 \mathrm{egg}$. The larva absorbed its yolk and was fed commercial trout food (Silver Cup). After attaining a length of $29 \mathrm{~mm}$, it died of unknown causes on the 259 th day of incubation ( 87 days after hatching).

On 7 November 1978, four gill nets were set in the sampling area by United States Fish and Wildlife Service biologists. The potential for lake trout reproduction was assessed by CPE (catch per unit of effort), which was the number of spawners captured overnight per 91 linear meters of $12.7-$ or $14.0-\mathrm{cm}$ mesh nylon gill net. Two nets set at $5.6 \mathrm{~m}$ produced CPE's of 33 (14 male, 19 female) and 20 (11 male, 9 female), respectively, and nets set at $9.1 \mathrm{~m}$ had CPE's of 49 (4l male, 8 female) and 21 (19 male, 2 female) spawners. We judged the potential for trout reproduction in the study area to be excellent, based upon comparison of our CPE data with CPE data from naturally reproducing Lake Superior trout discussed by Peck (1979). Similar nets were set on 13 November 1979 at $7.5 \mathrm{~m}$. Catch data were unavailable although many ripe spawners of both sexes were captured. Biologists again judged lake trout reproductive potential to be excellent, based upon comparison of 1979 with 1978 catches.

Presence of ripe and spent fish in the study 
area, as well as the discovery of viable, fertilized eggs in 1978 and 1979, indicate that lake trout spawned on or near this reef. This finding is significant in at least two respects: first, it is the most southerly observation of the deposition of fertilized eggs by planted lake trout in Lake Michigan; and second, the presence of eggs proved that spawning occurred in a traditional spawning area over natural substrate. An area within the moraine that we sampled, historically referred to as Honeycomb Reef, was reported to be a good lake trout spawning ground in the late 1800's (Smith and Snell 1891). Spawning is believed to have occurred in the study area during the 1970's (personal communication from L. Wells, Great Lakes Fishery Laboratory, Ann Arbor, Michigan), but apparently there was no successful overwintering of eggs and survival of larvae.

Martin and Olver (1980) noted that, while eggs immediately filter down through the interstices in rocks at oviposition, it may take several days for the eggs to fully settle and wedge into spaces in the substrate. During this period, the eggs may be subject to scattering or transport because of their semibuoyant nature. Eggs deposited over unsuitable substrate (e.g., interstices too shallow or wide) would undoubtedly be subjected to increased disturbance, dispersal, and mortality. During 1979 , the largest concentration of eggs was found inshore at Station D. To what extent this concentration of eggs represented depth-selective spawning or simply onshore transport of eggs by wave action is unknown. Nevertheless, the net result was that most of the eggs would have been exposed to harsh environmental conditions (wave action, currents, ice scour) associated with this extreme inshore area.

Twice during April, four times during May, and three times during June 1980 , in conjunction with a different project, divers returned to the study area and visually examined the substrate and dislodged rocks at 3,6, 9, and $12 \mathrm{~m}$ to search for eggs. None were found. Gillnetting conducted concurrently with diving at these depths yielded about 500 yellow perch. Examination of the stomachs revealed no trout eggs or fry.

\section{Discussion}

Lake trout stocked in Lake Michigan since 1965 were produced from four brood stocks-
Lake Superior strain, Manitoba strain, Apostle Island strain, and Green Lake strain (descended in part from native lake trout which spawned on the Milwaukee-Sheboygan Reef Complex in Lake Michigan). As discussed by Brown et al. (in press), the four brood stocks may have different physiological, behavioral, and developmental characteristics, and only the Green Lake strain is descended from fish native to Lake Michigan. Given the range of depths $(0.6-85 \mathrm{~m})$ and substrate conditions (cobble, boulders, honeycombed limestone outcroppings, gravel, and clay) associated with the various traditional spawning areas in Lake Michigan alone, area-specific adaptations may have existed among the now-extinct Lake Michigan lake trout stocks (Brown et al., in press). The eggs currently deposited in the study area may not be adapted to this harsh inshore environment. For example, eggs deposited at 3-12 m among rounded cobble with limited interstices would be more vulnerable to effects of turbulence, dislocation, and abrasion than eggs deposited at $60 \mathrm{~m}$ on the mid-lake, MilwaukeeSheboygan Reef Complex.

Dislocation has repeatedly been demonstrated to be a cause of egg loss. During 9-10 November 1975 , an intense storm passed through the Great Lakes region and thousands of windrowed lake trout eggs were observed along the beach at the D. C. Cook Nuclear Plant, Bridgman, Michigan (Jude et al. 1979), and near Charlevoix, Michigan (personal communication from T. M. Stauffer, Marquette Fisheries Research Station, Marquette, Michigan). Similar observations along eastern Lake Michigan have been reported to us over the past few years. Extensive bottom scouring by winter storms in an area used by spawning lake trout of hatchery origin in Henderson Harbor in eastern Lake Ontario, has also been observed (personal communication from R. Bergstedt, Great Lakes Fishery Laboratory, Ann Arbor, Michigan). Clady and Hutchinson (1975) also cited windinduced dislocation and discussed mortality associated with beaching of eggs spawned by yellow perch in Oneida Lake, New York.

If physiological and behavioral adaptation to depth and substrate conditions at a given spawning site plays a significant role in the genetic differentiation of native populations of lake trout, as suggested by Brown et al. (in press), development of self-sustaining populations may be hindered by the length of time 
required for development of area-specific genotypes.

Live eggs were collected by other investigators during the fall at North Point Reef in northern Lake Michigan near Charlevoix, Michigan in 1973, 1974, and 1975, and in Grand Traverse Bay at Bower's Harbor and New Mission Point in 1976 (Wagner 1981). Substrates consisted of naturally occurring deposits of boulders, cobbles, gravels, and occasional sands. In all years, sampling for emergent fry with a variety of gear was conducted during the subsequent spring, but none were collected. During March-May 1977, 59 lake trout fry were entrained at the Traverse City Municipal Power Plant (WAPORA 1977). During that fall, live eggs of eyed and earlier stages were collected in Grand Traverse Bay from the intake crib at the Traverse City Municipal Power Plant and surrounding spilled rock, and from the Elmwood Marina riprap (Wagner 1981). In the following spring, eggs nearly ready to hatch and sac fry were collected at the power-plant intake crib; at Elmwood Marina, fry were collected but no eggs were observed (Wagner 1981). These data demonstrated that, since 1973, some spawning and limited survival of fry have occurred in northern Lake Michigan, but no lake-produced yearlings or older fish have been found.

Martin and Olver (1980) state, "due to the erratic nature of [lake trout] egg distribution amongst the rubble and their proclivity to disperse when disturbed, it is difficult to estimate egg density on the beds." In our study, egg densities ranged from 0 to $13 / \mathrm{m}^{2}$. Examination of the largest sample (Station D, 1979) revealed that four $(31 \%)$ of the eggs were alive, three (23\%) were dead but had been fertilized, and the other six were too damaged during pumping to distinguish their condition. Martin (1957) found egg densities in Ontario lakes ranged from 91 to $1,443 / \mathrm{m}^{2}$ (average, $538 / \mathrm{m}^{2}$ ). Hindley et al. (1977) observed lake trout egg densities of $8-69 / \mathrm{m}^{2}$ in Lake Simcoe, Ontario, and $70 \%$ of the eggs collected were alive. Peck (1978) found egg densities ranging from 0 to $13,400 /$ $\mathrm{m}^{2}$ (average, $450 / \mathrm{m}^{2}$ ) on an artificial substrate (rock-covered intake structure at the Upper Peninsula Power Company's Presque Isle Power Station) in Presque Isle Harbor, southern Lake Superior; $75 \%$ of the eggs collected were fertile, and less than $1 \%$ of the fertile eggs were dead. In northern Lake Michigan, Wagner (1981) collected 10 eggs from a $21.2-\mathrm{m}^{2}$ area $\left(0.38 \mathrm{eggs} / \mathrm{m}^{2}\right)$, and $23 \mathrm{eggs}$ from a $297.3-\mathrm{m}^{2}$ area $\left(0.07 \mathrm{eggs} / \mathrm{m}^{2}\right)$.

Since both the Lake Simcoe and southern Lake Superior trout populations are fully to partly self-sustaining, the preceding data suggest that egg densities may be critically low on Lake Michigan reefs. An alternate possibility is that sampling may have missed the areas with good spawning substrate. Brown et al. (in press) note that traditional spawning reefs and shoals contain many different types of substrate, only a small fraction of which may be suitable for the protection and incubation of lake trout embryos. Stamm et al. (1981) discuss this sampling problem and the design of an appropriate reef survey and lake trout egg-sampling program. The problem of whether these low densities are due to an insufficient number of spawners on reefs or to egg losses after deposition must be resolved if self-sustaining populations are to be reestablished in Lake Michigan.

Viability of lake trout eggs from hatchery brood stock is high. Normal hatchery yield from fertilization of green eggs to the eyed stage (development of visible eye pigmentation) is $60-75 \%$, and survival from the eyed stage to hatching is $85 \%$ (personal communication from L. C. Wubbels, Jordan River National Fish Hatchery, Elmira, Michigan). Laboratory incubation of the live eggs we collected from Lake Michigan during 1978 and 1979 resulted in $50 \%$ and $20 \%$ survival, respectively, from fertilization to hatching. From 48 hours after water hardening to the eyed stage, lake trout eggs are particularly sensitive to perturbations (e.g., abrasion, agitation, bruising, physical deformation from shear forces). Such perturbations undoubtedly occurred during pumping and handling of eggs we collected, a factor that may have reduced survival of our eggs. The extremely small sample sizes and very sparse egg distributions, however, precluded valid statistical analyses of differences between observed and expected survival $(85 \%$ in the hatchery) from fertilization to hatching.

During April-August 1980, after our study was completed, 60 lake trout fry were collected in trawls and sleds towed in the vicinity of the J. H. Campbell Power Plant at Port Sheldon, Michigan, in southeastern Lake Michigan (Jude et al. 1981). Fry ranged from 22 to $62 \mathrm{~mm}$ in 
total length and weighed from 0.1 to $1.8 \mathrm{~g}$. Presumably, spawning had occurred over a newly placed (fall 1979) riprap stretching from shore to the $11-\mathrm{m}$ depth contour. The recovery of lake trout fry in 1980 at the Campbell Plant near Port Sheldon, north of our study area in eastern Lake Michigan (Fig. 1), may have been the result of optimal spawning substrate and incubation conditions, including a substrate composed of newly placed clean riprap (free of silt and periphyton), variable in size, and interspersed with deep crevices within which the eggs and sac fry were protected from ice scouring and wave action. Fish moving alongshore would have encountered the reef (positioned perpendicular to shore) which offered a clean spawning substrate extending over a wide range of depths $(0.5-11 \mathrm{~m})$. The relatively clean condition of the riprap as a habitat that we observed probably was responsible for the sparse populations of benthic macrofauna such as sculpins and crayfish, as discussed by Dorr and Miller (1975) and Dorr and Jude (1980).

Our study suggests that suboptimal incubation conditions at sites being used for spawning by planted fish may be limiting lake trout reproduction in Lake Michigan. Insufficient numbers of eggs, combined with adverse incubation conditions (turbulence, abrasion, sedimentation, and suffocation) may be hindering reproductive success. Also, fish may not be genetically adapted to this spawning location in that aspects of their reproductive behavior (depth and substrate selection) or egg physiology may not be compatible with site-specific incubation conditions.

\section{Acknowledgments}

We would like to acknowledge the captain, Richard Eichler, and crew of the United States Fish and Wildlife Service R/V Cisco for assistance during field operations. Lee H. Somers, University of Michigan Underwater Technology Laboratory, contributed essential diving equipment and advice. This study would not have been possible without the dedication of Great Lakes Research Division divers George R. Heufelder, Karl S. Luttrell, George E. Noguchi, pHred Peterson, Thomas Rutecki, Philip J. Schneeberger, and James A. Wojcik, and Great Lakes Fishery Laboratory (GLFL) field assistants John B. Hamilton and Kurtis L. Vin- cent. William H. Berlin (GLFL) assisted by examining developmental stages of eggs. We thank Paul M. Haack, Ross M. Horrall, Frank J. Tesar, and Wayne A. Willford for reviewing the manuscript. This project was supported, in part, by (1) the United States Fish and Wildlife Service (Great Lakes Fishery Laboratory, Ann Arbor, Michigan), (2) grants to John C. Ayers, Great Lakes Research Division, from the Indiana \& Michigan Power Company, a subsidiary of American Electric Power Service Corporation (New York, New York), and (3) grants to David J. Jude from Consumers Power Company (Jackson, Michigan).

\section{References}

Brown, E. H., Jr., G. E. Eck, N. R. Foster, R. M. Horrall, and C. E. Coberly. In press. Historic evidence for discrete stocks of lake trout in Lake Michigan. Canadian Journal of Fisheries and Aquatic Sciences.

Christie, W. J. 1974. Changes in the fish species composition of the Great Lakes. Journal of the Fisheries Research Board of Canada 31:827854.

Clady, M. D., and B. Hutchinson. 1975. Effect of high winds on eggs of yellow perch, Perca flavescens, in Oneida Lake, New York. Transactions of the American Fisheries Society 104:524-525.

Dorr, J. A., III, ANd T. J. Miller. 1975. Underwater operations in southeastern Lake Michigan near the Donald C. Cook Nuclear Plant during 1974. Benton Harbor Power Plant limnological studies. Part XXII. Great Lakes Research Division Special Report 44. University of Michigan, Ann Arbor, Michigan, USA.

Dorr, J. A., III, And D. J. Jude. 1980. SCUBA assessment of abundance, spawning, and behavior of fishes in southeastern Lake Michigan near the Donald C. Cook Nuclear Plant, 1975-1978. Michigan Academician 12:345-364.

Eschmeyer, P. H. 1957. The lake trout (Salvelinus namaycush). U.S. Fish and Wildlife Service, Fishery Leaflet 441. Ann Arbor, Michigan, USA.

Hindley, B., D. Speller, and R. Des Jardine. 1977. A winter investigation of three lake trout and whitefish spawning shoals in Lake Simcoe, Ontario. Lake Simcoe Fisheries Assessment Unit, Ministry of Natural Resources, Toronto, Ontario, Canada.

Horns, W. H., and J. J. Magnuson. In press. Crayfish predation on lake trout eggs in Trout Lake, Wisconsin. International Council for the Exploration of the Sea, Early Life History Symposium, 1979. Woods Hole, Massachusetts, USA.

Jude, D. J., F. J. Tesar, J. C. Tomlinson, T. J. MilLer, N. J. Thurber, G. G. Godun, and J. A. DORR III. 1979. Inshore Lake Michigan fish 
populations near the D. C. Cook Nuclear Power Plant during preoperational years—1973, 1974. Great Lakes Research Division Special Report 71. University of Michigan, Ann Arbor, Michigan, USA.

Jude, D. J., S. A. Klinger, and M. D. Enk. 1981. Evidence of natural reproduction by planted lake trout in Lake Michigan. Journal of Great Lakes Research 7:57-61.

Loftus, K. H. 1976. Science for Canada's fisheries rehabilitation needs. Journal of the Fisheries Research Board of Canada 33:1822-1857.

Manz, J. V. 1964. A pumping device used to collect walleye eggs from offshore spawning areas in western Lake Erie. Transactions of the American Fisheries Society 93:204-206.

Martin, N. V. 1957. Reproduction of lake trout in Algonquin Park, Ontario. Transactions of the American Fisheries Society 86:231-244.

Martin, N. V., ANd C. H. Olver. 1976. The distribution and characteristics of Ontario lake trout lakes. Fisheries and Wildlife Branch Report 97. Ministry of National Resources of Ontario, Toronto, Ontario, Canada.

Martin, N. V., And C. H. Olver. 1980. The lake charr Salvelinus namaycush. Pages 205-277 in E. K. Balon, editor. Charrs. Dr. W. Junk bv Publishers, The Hague, The Netherlands.

Peck, J. W. 1978. Population dynamics of lake trout in early life history stages and characteristics of an artificial spawning reef. Pages 257-271 in Dingell-Johnson Annual Report, Project Number F-35-R-4, Michigan Department of Natural Resources, Fisheries Division, Lansing, Michigan, USA.

PECK, J. W. 1979. Utilization of traditional spawning reefs by hatchery lake trout in the upper Great Lakes. Michigan Department of Natural Resources, Fisheries Division, Fisheries Research Report 1871, Lansing, Michigan, USA.

PychA, R. L. 1972. Rehabilitation of spawning runs of lake trout in Lake Superior. Pages 11-29 in Minutes of the 1972 Lake Superior Committee Meeting. Great Lakes Fishery Commission, Ann Arbor, Michigan, USA.

Rybicki, R. W., AND M. Keller. 1978. The lake trout resource in Michigan waters of Lake Michigan, 1970-1976. Michigan Department of Natural Resources, Fisheries Division, Fisheries Research Report 1863, Lansing, Michigan, USA.
Scott, W. B., and E. J. Crossman. 1973. Freshwater fishes of Canada. Fisheries Research Board of Canada Bulletin 184.

Smith, H. M., AND M. M. Snell. 1891. Review of the fishes of the Great Lakes in 1885. Pages 1333 in Report to the United States Fishery Commission for 1887, Part XV, Washington, D.C., USA.

SмiтH, S. H. 1968. Species succession and fishery exploitation in the Great Lakes. Journal of the Fisheries Research Board of Canada 25:667693.

Stamm, D., P. Keillor, and R. Horrall. 1981. A survey of Lake Michigan reefs and shoals. Volume I: Text. Marine Studies Center and Sea Grant Institute Report 45. University of Wisconsin-Madison, Madison, Wisconsin, USA.

Stauffer, T. M. 1979. Effects of DDT and PCB's on survival of lake trout eggs and fry in a hatchery and in Lake Michigan 1973-1976. Transactions of the American Fisheries Society 108:178-186.

Stauffer, T. M., ANd W. C. Wagner. 1979. Fish predation on lake trout eggs and fry in the Great Lakes, 1973-1978. Michigan Department of Natural Resources, Fisheries Division, Fisheries Research Report 1865, Lansing, Michigan, USA.

Swanson, B. L. 1973. Lake trout homing, migration and mortality studies, Lake Superior. Wisconsin Department of Natural Resources, Fishery Management Branch, Management Report 65, Madison, Wisconsin, USA.

WAGNER, W. C. 1981. Reproduction of planted lake trout in Lake Michigan. North American Journal of Fisheries Management 1:159-164.

WAPORA, INC. 1977. 316(b) Demonstration Report. Traverse City Municipal Power Plant, Traverse City, Michigan. Final report. WAPORA, Charleston, Illinois, USA.

Wells, L., ANd A. L. McLain. 1973. Lake Michigan: man's effects on native fish stocks and other biota. Great Lakes Fishery Commission Technical Report 20, Ann Arbor, Michigan, USA.

Willford, W. A. 1980. Chlorinated hydrocarbons as a limiting factor in the reproduction of lake trout in Lake Michigan. Pages 75-83 in W. R. Swain and V. R. Shannon, editors. Proceedings of the Third US-USSR Symposium on the Effects of Pollutants on Aquatic Ecosystems, Washington, D.C., USA. 